\title{
SPEECH PORTRAIT OF A POLITICAL LEADER (BASED ON THE INAUGURAL ADDRESSES OF THE RUSSIAN AND US PRESIDENTS)
}

\author{
Rimma R. Galiakberova ${ }^{1}$ \\ Dilyara B. Garifullina ${ }^{2}$ \\ Lyutsiya G. Khismatullina ${ }^{3}$
}

\begin{abstract}
An inaugural address is part and socio-political course of the country. of the political reality of the country, and represents an essential moment in delivering political visions for the future by presidents. The given paper deals with the inauguration speeches of Vladimir Putin (2018) and Donald Trump (2017) and is aimed at analyzing the role of verbal means in forming the Thus, each president's inauguration context model is mostly characterized by a different set of linguistic means. The paper findings may be useful for researchers who deal with interdisciplinary studies, political and cognitive linguistics, political discourse and communication analysis.
\end{abstract} speech portraits of political leaders. By means of comparative content analysis we looked for grammatical, lexical and stylistic elements peculiar to a specific linguistic persona while comparing the speeches of the presidents as well as we attempted to determine the specific national backgrounds of political discourse. We found out that the speech portrait of a country leader is strongly related to his national identity, mentality

Keywords: linguistics, political discourse, inaugural address, comparative analysis, president, linguistic persona.

\section{Introduction}

Political linguistics is one of the most challenging fields of modern linguistic studies which focuses on (1)

\footnotetext{
1 Kazan Federal University, Tel.: +79272497546. E-mail: rimma.galiakberova@gmail.com

${ }^{2}$ Kazan Federal University

${ }^{3}$ Kazan Federal University
} 
lingvomental portrait of political world, that is mental fields, political concepts, disvalues and values, stereotypes in political discourse and (2) political communication and related to its political discourse, tactics and strategies in political communication, genres of political speech, political text, political speech (Sukhanov, 2018). Thus, the core notion in modern political linguistic studies is political discourse which comprises all speech acts used in political discussions as well as rules of public policy (Chudinov, 2008).

Van Dijk, one of the leading scholars in this field, states that discourse plays a pivotal role in the exercise of power. It expresses social cognition and may thus 'manage the minds' of other groups and their members (Van Dijk, 2015). It affects the public at large, when a political actor in a political context attempts to prompt or influence social action through persuasion (McClay, 2017). Parshina also points out that a political text aims at linguistic manipulation, which is achieved with the help of linguistic means (Parshina, 2007). The idea is supported by another scholar Baigunakova, who states that political discourse is a specific type of political communication characterized by a high degree of manipulating the minds of people (Baigunakova, 2018). In this regard, it is significant to study and reveal key mechanisms of political communication which includes the most effective means of linguistic influence on public employed by politics.

In our study, we focus on political discourse in real domain, offered by Sheigal, the founder of semiotic approach to political discourse (Sheygal, 2004); when a speaker and a listener take on particular roles as a result of which appear speech acts affected by linguistic and extralinguistic factors. Therefore, we can say that in different social environments political discourses have different lingvocultural elements as each country has its own language, history and traditions, specific mentality and model of political communication. Every political figure is put into this lingvocultural frame.

One of the types of political communication is inaugural address. Generally, inaugural speech is attributed to Epideictic Rhetoric. According to American researchers, Presidential inaugural (1) unifies the audiences by reconstituting it as "the people" who 
witness and ratify the ceremony; (2) rehearses shared values drawn from the past; (3) enunciates the political principles that will guide the new administration; (4) demonstrates that the President appreciates the requirements and limitations of executive power; and (5) achieves these ends through means appropriate to epideictic discourse (Campbell \& Jamieson, 1985).

Despite countless researches of inaugural discourse in foreign linguistics and an increasing number of studies in Russian linguistic science, there is limited discussion of its ideological basis, proper criteria for selecting and generalizing the linguistic corpus, especially, when inaugurals of presidents of different countries are compared.

The given paper is an endeavor to determine speech portraits of the Russian and US Presidents Thus, it could contribute to deeper understanding of the verbal, mental, cultural and national nature of inaugural addresses.

\section{Methods}

\section{Research objectives}

In order to carry out the comparative study of linguistic means under study we stated the following objectives:

- to review the existing works devoted to the research topic and analyze the main approaches to studying political discourse and political communication in foreign and Russian linguistics;

- to analyze the role of language in the formation of a speech portrait of a political leader

- to reveal the set of grammatical, lexical and stylistic means peculiar to a specific linguistic persona.

\section{Theoretical and empirical}

\section{methods}

Our research is based on the following key methods:

- theoretical methods of analysis and synthesis, including the analysis of the theoretical literature devoted to the research problem and generating the reviewed linguistic knowledge into the relevant research approach;

- empirical methods including content analyses of inaugural speeches and selection of research data, which was examined in the light of comparative analysis. 


\section{Body of Data}

The body of data comprises the transcripts of the inaugural addresses of the Russian President V. Putin (2018) and the US President D. Trump (2017). Putin's speech includes 1263 words, while Trump's speech includes 1503 words. The present study deals with the words and phrases frequently used by two leaders and emphatic expressions found in their speeches.

\section{Results And Discussion}

In preparation to inaugural address, every new leader appertains to writing inaugural speech with special quiver and caution, to the choice of lexico-grammatical means and the manner of presenting information in front of large audience. Salutation should be considered of highly importance, which sets the tone to the whole solemn speech.

V.Putin begins his speech with appealing: "Uvazhaemyye grazhdane Rossii! Damy i gospoda! Dorogieye druzia!" Change of the expression "uvazhaemyye grazhdane" to "dorogieye druzia" by the end of the appeal shortens the distance with the audience. Then follows salutation "vsekh grazhdan nashey velikoy Rodiny

i sootechestvennikov za rubezhom, vsekh, kto smotrit ili slushayet translyatsiyu etoy torzhestvennoy tseremonii, vsekh, kto prisutstvuet zdes, v istoricheskikh zalakh Kremlya I na drevney sobornoy ploshchadi." (Putin, 2018).

D.Trump begins his speech with appealing to the present presidents: «Chief Justice Roberts, President Carter, President Clinton, President Bush, President Obama» (Trump, 2017), and then to Americans «fellow Americans and people of the world». Whereby word combinations «fellow Americans» tells about partnership and belonging of all and including the president to one society, marking equality of all. American president finishes his speech with the word "thank you". This "thank you" is polysemantic: it can be considered as appreciation for previous work, for voting, for coming.

The president of Russia clearly pronounces what he is grateful for: "Ot vsego serdtsa blagodaryu grazhdan Rossii zavashu splochennost, za veru v to, chto my mozhem mnogoye izmenit $\mathrm{k}$ lutchshemu." "Eshe raz khochu sakzat spasibo - spasibo za tot uroven iskrenney 
podderzhki, kotoryy vy, grazhdane Rossii, okazali mne na vyborakh Prezidenta nashey strany" (Putin, 2018).

\section{Grammatical means}

It is necessary to mention the usage of pronouns "we" and "our" in speeches of presidents. These pronouns are social markers. As a rule, the main meaning of these pronouns in the context is nation in the whole, people and the country. Thus, distance is overcome and rapport between speaker and audience is enhanced. The fact that presidents barely used personal pronoun "I" speaks about priority of collective origin over personal origin in mentality of states of the leaders. This can be explained by speech's type, speaker's purpose is not to mark own status. Message of both presidents is to serve the nation and do everything possible for the prosperity of the nation. However, it should be marked that V.Putin uses ellipsoidal construction of substitute pronoun "I": "Shitayu svoim dolgom I smyslom vsey svoyey zhizni selat vse dlya Rossii, dlya ee nastoyashego I budushego - mirnogo I protsvetayushego, dlya sberezheniya I prodolzheniya nashego velikogo naroda, dlya blagopoluchiya v kazhdoy rossiyskoy semye. Zaveryayu vas, tselyu moyey zhizni, raboty budet, kak I prezhde, sluzheniye lyudyam, nashemu Otechestvu" (Putin, 2018). This makes the expression less categorical. American president pronounces personal pronoun "I" once, which in combination with hyperbole adds grandiosity and gaudiness to his speech: "I will fight for you with every breath in my body and I will never ever let you down." (Trump, 2017).

Tactics of appellation to historical past is used by Putin: "My znayem, chto v 1990-ye I v nachale 2000-kh godov naryadu s davno nazrevshim i absolyutno neobkhodimymi istoricheskimi peremenami na dolyu nashego Otechestva I nashikh lyudey vypali ochen tyazhelyye ispytaniya." (Putin, 2018).

«...za bolee chem tysyacheletnyuyu istoriyu Rossiya ne raz stalkivalas s epokhami smut $\mathrm{i}$ ispytaniy $\mathrm{i}$ vsegda vozrozhdalas..." In such way tenacity and endurance of the Russian nation is underlined by the Russian president.

D.Trump's same appellation sounds as critics of politics of predecessors: "For many decades, we've 
enriched foreign industry at the expense of American industry; subsidized the armies of other countries, while allowing for the very sad depletion of our military. We've defended other nations' borders while refusing to defend our own. And spent trillions and trillions of dollars overseas while America's infrastructure has fallen into disrepair and decay. We've made other countries rich, while the wealth, strength and confidence of our country has dissipated over the horizon." (Trump, 2017).

In Trump's speech traditional American values actively verbalize, such as freedom, love to Motherland and the idea of strong national state: "We must speak our minds openly, debate our disagreements honestly, but always pursue solidarity. When America is united, America is totally unstoppable." (Sheygal, 2004). Trust from society is reached by addressing to the bible and God:" The bible tells us how good and pleasant it is when God's people live together in unity." (Trump, 2017).

\section{Stylistic means}

Integral part of successful speech is usage of stylistic means to achieve certain goal while speaking engagement. Stylistic peculiarities of the language can enhance influence of the speaker on audience and it is widely used by both presidents.

$$
\text { D.Trump's }
$$

speech representation of patriotism is reached by parallel constructions and repitions: "Together, we will make America strong again. We will make America wealthy again. We will make America proud again. We will make America safe again. And yes, together we will make America great again. We share one heart, one home, and one glorious destiny." [9] Anaphoric repition of lexical units America, American enhances sense of patriotism: "From this day forward, it's going to be only America first, America first. We will get our people off of welfare and back to work, rebuilding our country with American hands and American labor. We will follow two simple rules; buy American and hire American." (Trump, 2017).

V.Putin's speech is rich of parallel constructions and repitions: «No istoriya ne proshayet tolko odnogo: bezrazlichiya i neposledovatelnosti, rasslablennosti b samouspokoennosti, osobenno segodnya, $\mathrm{v}$ perelomnoye vremya, $\mathrm{v}$ perelomnuyu epokhu, $\mathrm{v}$ epokhu burnykh izmeneniy vo vsem 
mire. Eshe raz khochu skazat spasibo spasibo za tot uroven iskrenney podderzhki, kotoriy vy, grazhdane Rossii, okazali mne na vyborakh Prezidenta nashey strany." (Putin, 2018). Special emotionality and rhythm is given by gradation: "Novoye kachestvo zhizni, blagopoluchiye, bezopasnost, zdorovye cheloveka - vot chto segodnya glavnoye, vot chto $\mathrm{v}$ tsentre nashey politiki. Imenno $\mathrm{v}$ garmonichnom edinstve svobodnogo obshestva i silnogo, deesposobnogo, demokraticheskogo gosudarstva vizhu prochnuyu osnovu dlya razvitiya Rossii." (Putin, 2018).

D.Trump emphasizes attention at the change of political policy with the help of antithesis: "Washington flourished, but the people did not share in its wealth. Politicians prospered, but the jobs left and the factories closed. The establishment protected itself, but not the citizens of our country. Their victories have not been your victories. Their triumphs have not been your triumphs. And while they celebrated in our nation's capital, there was little to celebrate for struggling families all across our land." (Trump, 2017).

On the other hand, inversion, brings attention to the fact, that the time of changes has come: "From this day forward, a new vision will govern our land. From this day forward, it's going to be only America first, America first." (Trump, 2017).

Current situation of America is colorfully described by metaphoric expression "...mothers and children trapped in poverty in our inner cities; rusted out factories scattered like tombstones across the landscape of our nation; an education system flush with cash, but which leaves our young and beautiful students deprived of all knowledge; and the crime and the gangs and the drugs that have stolen too many lives and robbed our country of so much unrealized potential." (Trump, 2017). Comparison «scattered like tombstones» vividly describes crisis in industrial field. Indeed fragments about equality of Americans can be called poetical :"...whether we are black or brown or white, we all bleed the same red blood of patriots. And whether a child is born in the urban sprawl of Detroit or the wind-swept plains of Nebraska, they look up at the same night sky, they fill their heart with the same dreams, and they are infused with the 
breath of life by the same almighty creator." (Trump, 2017).

In Russian speech metaphoric expression "dremucheye okhranitelstvo I byurokraticheskaya mertvechina" also underlines president's negative attitude toward bureaucracy that cramps development and improvement of modern Russian society: “...takoy ryvok sposobno obespechit tolko svobodnoye obshchestvo, kotoroye vosprinimayet vse novoye i vse peredovoye i ottorgayet nespravedlivost, kosnost, dremucheye okhranitelstvo i byurokraticheskuyu mertvechinu - vse to, chto skovivayet lyudey, meshayet im $\mathrm{v}$ polnoy mere raskrytsya...". However, comparison with Phoenix underlines endurance and immortality of Russia “... za bole chem. Tysyacheletnyuyu istoriyu Rossiya ne raz stalkivalas $\mathrm{s}$ epokhami smut i ispitaniy i vsegda vozrozhdalas, kak ptitsa feniks..." (Putin, 2018).

\section{Lexical means}

From lexical point of view usage of synonyms by Trump should be marked, which is, by the way, common among English-speaking speakers: «great prosperity and strength, friendship and goodwill, good and pleasant, thrive and prosper».
It is typical for Putin to use set phrases: "Sobrav volyu v kulak, po plechu slozhnyye zadachi, otstaivat interesy". Favoured phrase "Vremeny na raskachku net" is pronounced the same. Usage by him of archaism "radeet za stranu" is interesting. It marks solemnity of the situation and gives the speech citizen-patriotic connotation.

In conclusion American elect emphasizes attention at future prosperity of America. He thanks American nation and as is common addressed to the God: "God bless you. And God bless America!" (Putin, 2018).

D.Trump sort of "transfers" power to nation, his idea is clear: from now Americans themselves will take decisions and all actions will be done first of all for Americans, and after that support to other countries will be given. D.Trump's speech is more aggressive and categorical, he promises to vanish from the Earth terrorism and that injustice towards Americans that had existed before the day when he was elected the president of the country.

V.Putin finishes his speech with the promise to do everything that is possible in his power to make Russia successful country. His speech involves 
call to action for all and every in building the future of Russia; in spite of difficulties that befell Russian people, they should "move forward". Also priority in economical, social development inside the country is underlined.

\section{Summary}

The figure of country's political leader and his most important address, inaugural, have been the deserving objects of extensive scientific interest. In American history this speech act was first made by George Washington in 1789, while for Russia it is comparatively a new political practice the first inaugural was made by Boris Yeltsin in 1991. Since then, there have been pronounced five inaugurals in Russia to compare with 58 in the USA. So there are different scopes of academic research viewing the topic.

A great number of studies on President's speech content pattern have been made in American and foreign political linguistics. The scholars consider inaugurals a useful sample of speech communication in many respects: they are among the most widely attended to presidential communications, they are a distinct genre and they have tremendous political significance (Coe \& Neumann, 2011). A handful of studies have examined an individual president's inaugural speech (Campbell Bailey, Lindholm, Mahoney, Banks,), presidential rhetoric (Coe, Lim, Teten, Cohen), carried out content analysis of presidential communications (Lim, Coe).

In Russian linguistics a handful of studies viewed the structure and key elements of inaugurals, its content and functions. There are research works that analyze Russian Presidents' inaugural addresses (Gafrilova, Markova, Kharlamova, Szymula) as well as American Presidents' (Yudina, Akinina, Aslanova, Khromenkov and others.

We should note that researches mostly analyze individual inaugurals. Comprehensive full-scale surveys including two or more presidential rhetoric are carried out quite rarely. As for comparative content analysis this paper represented an endeavor to demonstrate the typological similarities and differences in the structure, vocabulary, functions and historicocultural backgrounds of the Russian and English inaugurals. 


\section{Conclusions}

Having analyzed the inaugurals of Vladimir Putin and Donald Trump we can assume that both are rhetorically competent and smart speakers. They enunciated their ideas and intentions within a similar range of vocabulary, focusing more on positive aspects rather than negative ones (bright future, welfarism of the nation, happy people).

The inaugural speeches of the Presidents were studied from grammatical, lexical and stylistic points of view. As for the grammar of speeches, they are rich in pronouns, extended sentences, Active Voice and tenses. Stylistically, the Presidents' speeches are emotional and value marked; there are bright epithets and metaphors, repetitions, parallel constructions and others. As for the vocabulary, both Presidents appeal to such words as country, president, nation, future. Putin also quite often mentions history, motherland and responsibility. Trump uses dream, God, wealth, job, family, which belong to the American set of values.

Distinct elements in the inaugural addresses stated in the paper demonstrate the difference of political realities of countries. Inaugurals reflect the history, culture, social development of the country, its mentality and national identity; that is why comparative content analysis of inaugurals will always of vital significance.

\section{Acknowledgements}

The work is performed according to the Russian Government Program of Competitive Growth of Kazan Federal University.

\section{References}

Sukhanov, Yu. (2018). Politicheskiy diskurs kak ob'ekt lingvisticheskogo analiza. RUDN Journal of Language Studies, Semiotics and Semantics, 9, 200-212.

Chudinov, A. P. (2008). Politicheskaya lingvistika. Moscow.

Van Dijk, T. A. (2015). Critical Discourse Studies: A sociocognitive Approach (new version). Methods of critical discourse analysis, London: Sage, 63-85.

McClay, R. (2017). Us and them: A descriptive analysis of Donald Trump's 
Periódico do Núcleo de Estudos e Pesquisas sobre Gênero e Direito

Centro de Ciências Jurídicas - Universidade Federal da Paraíba V. 8 - No 07 - Ano 2019 - Special Edition

ISSN | 2179-7137 | http://periodicos.ufpb.br/ojs2/index.php/ged/index campaign speeches. Unpublished Master

Thesis. University of Birmingham.

Retrieved by https://www. birmingham.

ac. uk/Docum ents/college-

artslaw/cels/essays/appliedlinguistics/M

cClay2017. Trump-Speech-Discourse-

Analaysis. pdf.

Parshina, O. N. (2007). Rossiyskaya politicheskaya rech'. Teoriya i praktika. M.: LKI.

Baigunakova, C. O. (2018). Problemy issledovaniya politicheskogo diskursa $\mathrm{v}$ kognitivnoy lingvistike. Vestnik KazNU, Almaty. [Electronic resource] https://articlekz.com/article/22215.

Sheygal, E. I. (2004). Semiotika politicheskogo diskursa. M.: Gnozis.

Campbell, K. K., \& Jamieson, K. H. (1985). Inaugurating the presidency. Presidential Studies Quarterly, 15(2), 394-411.

Trump, D. (2017). The Inaugural Address. [Electronic resource], https://www.whitehouse.gov.

Putin vstupil v dolzhnost'prezidenta, V. (2018). RF; vpervye srok polnomochiy glavy gosudarstva ischislyaetsya 6 godami [Elektronnyy resurs].

Coe, K., \& Neumann, R. (2011). The major addresses of modern presidents: Parameters of a data set. Presidential Studies Quarterly, 41(4), 727-751.

Yudina, O. A. (2019). Rol'

inauguratsionnoy rechi $\mathrm{v}$ politicheskoy kommunikatsii: harakteristiki, funktsii I osobe politichesknnosti perevoda. Molodoy ucheniy, 5, 310-313. 